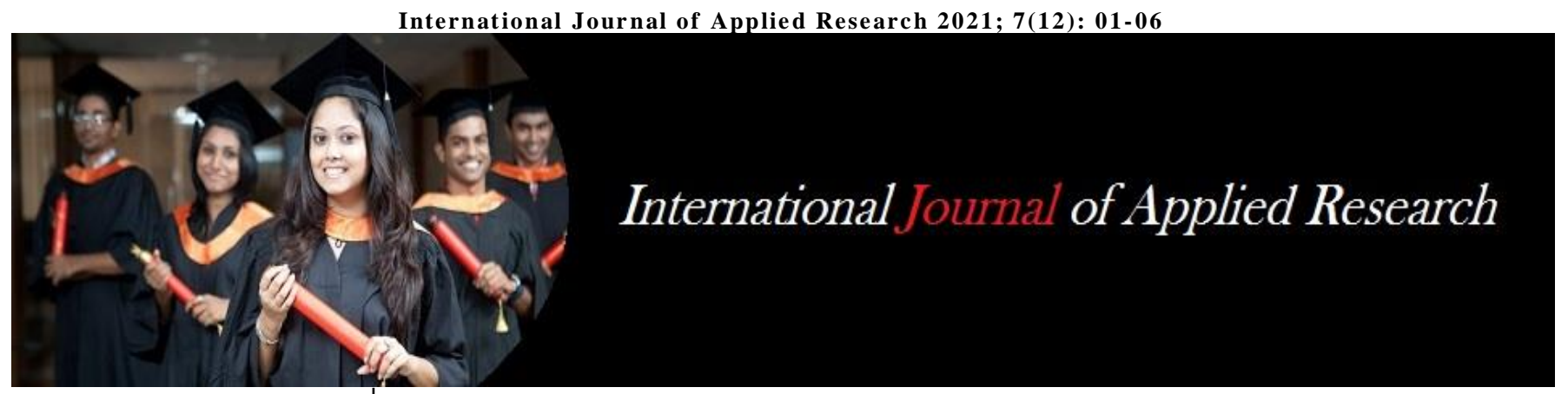

ISSN Print: 2394-7500 ISSN Online: 2394-5869 Impact Factor: 8.4 IJAR 2021; 7(12): 01-06 www.allresearchjournal.com

Received: 01-10-2021 Accepted: 03-11-2021

\section{Pooja Gupta}

Research Scholar, MMIM,

Maharishi Markandeshwar (Deemed to be) University, Mullana, Haryana, India

Dr. Rahul Hakhu Professor, MMIM, Maharishi Markandeshwar (Deemed to be University), Mullana,

Haryana, India
Corresponding Author: Pooja Gupta

Research Scholar, MMIM, Maharishi Markandeshwar (Deemed to be) University, Mullana, Haryana, India

\section{An empirical analysis of customer perception towards cashless transactions: A case study of Haryana}

\author{
Pooja Gupta and Dr. Rahul Hakhu
}

DOI: https://doi.org/10.22271/allresearch.2021.v7.i12a.9165

\begin{abstract}
The payment system has evolved over a long period of time. From barter system to coin-based currency and then a system in which payments were made by paper currency. Now a new system is evolving in which paper-based payments are being replaced by electronic or digital payments. In this digital era, the advancement in electronic and communication technologies has led to the development of alternate modes of payments. The Indian Government and RBI are continuously emphasizing the cashless transactions by using digital mediums like net banking, card payments, UPI Apps etc. Despite India is witnessing robust growth in cashless transactions, people are still hesitant to adopt cashless system. The present study examines the various modes of payment and focuses on the benefits and challenges of cashless payments perceived by customers. A primary data survey through a structured questionnaire has been conducted on 314 customers in selected districts of Haryana. The findings suggested that majority of the respondents agree that cashless transactions are convenient, user friendly and can also foster economic growth by reducing corruption. Major challenges in adoption of the cashless payment system are cyber security, inadequate facilities and lack of digital literacy. The results suggested an important policy direction is required for growth in cashless payments.
\end{abstract}

Keywords: cashless payments, cashless economy, digital India, awareness, perception

\section{Introduction}

Cashless Payment system is a system in which goods and services are exchanged without use of physical cash through digital modes. Basically, cashless transactions leads to a cashless economy, which describes an economic state in which the flow of cash within an economy is non-existent and all transactions are through digital/ electronic channels such as Dr. card/ Cr. card, NEFT, RTGS, Mobile wallets, UPI apps etc. In this digital era, with the fast-growing penetration of mobile devices and recent technological advancements has led to the development of new modes of payments including SMS payments, mobile applications, digital wallets and QR code scanning. In recent years, there has been a sharp inclination towards cashless methods of monetary exchange. Government is creating positive atmosphere for growth of digital payment in India by giving incentives and tax breaks. The launch of the 'Digital India' programme in 2015 reflects the government's commitment to bring efficiency and transparency in governance. Demonetization by government on 8th November 2016 pushed India towards cashless future.

According to Reserve Bank of India (RBI) as of September 2018, the number of debit and credit card has increased significantly to 990 million and 44 million respectively, showing a preference for cashless transactions ${ }^{[11]}$. Cashless payments offer advantages in terms of costs, convenience and fast transactions but it also pose a number of challenges in terms of required infrastructure, digital literacy and risks related to data security and cyber fraud. The present study examines the various modes of payment and focuses on the benefits and challenges of cashless payments perceived by customers.

\subsection{Cashless Payment Methods}

There are numerous modes for cashless payments which can be classified as paper based and electronic based. These are covered as under: 
1. Cheque: The cheque is one of the most established techniques for cashless payment. It is known technique to everybody. In this technique, a cheque is issued to a person or business for specified amount and deposited in the receiver's bank. After verifying the client details, bank issues the payment against cheque. Bank can dishonor the cheque if there is no sufficient balance in client account or in case of mismatch of signature. In order to avoid all these issues in cheque payments, people can goes through cashless transaction.

2. Demand Draft: Demand draft is another paper based method for cashless payment. It is used to transfer payment from one bank account to another on request of the client (drawer). It guarantees the payment of amount mentioned in draft in the name of payee. Compared to cheque, DD assures secure and on time payment as cheque can bounce and dishonor.

3. Credit / Debit card: to the use of cash when making purchases. Now a day's, the popular alternative of the cash, is card payment method through various cards like debit card, credit card and prepaid banking cards etc. The advantage of this card payment is convenience, easy payment and avoids carrying the cash. These cards are issued by banks along with 4 digit pin number to do all kind of transactions. Some of the most reputed and well-known card payment systems are Visa, Rupay and MasterCard.

4. Internet Banking: Internet banking refers to the process of carrying out banking transactions online. These may include many services such as transferring funds, opening a new account. Internet banking is often used to make online fund transfers via NEFT, RTGS or IMPS, bill payments etc. Customers can use all types of banking services through the bank website through log into his/her account by using a username and password.

5. Mobile Wallets: Mobile Wallets are the most popular way of cashless payment nowadays. The user can download a wallet application like paytm, mobikwik etc. from the play store on their mobile device. After registering the mobile number with the app, bank account or Dr./Cr card can be linked with the app. User has to provide $\mathrm{KYC}$ details to make or receive payments through these wallets.

6. UPI apps: UPI (Unified Payment Interface) is an application based payment system. This app enable transfer of money bank to bank and to users on 24/7 basis by providing details of bank account, IFSC code. The examples of few UPI Apps are BHIM app, SBI Pay, Axis Pay UPI App, Union Bank UBI App, PNB UPI, PhonePe and so forth.

7. QR Code Payments: QR (Quick response) code is a payment method where a payment is done by scanning a QR code from any mobile application. To make a payment, customer can scan the QR code displayed by the merchant from their mobile phone. It opens a payment link where customer can fill the amount to be paid and finally submit it.

\begin{tabular}{|l|l|}
\hline Paper Based Methods & Electronic Methods \\
• Cheque & - Debit/ Credit Card \\
- Demand Draft & - Internet Banking \\
& - Mobile Wallets \\
& - UPI Apps \\
& - QR code Payments \\
\hline
\end{tabular}

\section{Literature Review}

(Poonam 2016) in her study on mobile wallet analyzed that ease of transactions, secured profile and convenience in handling application put forth the benefits of wallet money and also concluded that business sectors like banking, retail, hospitality etc., are making use of mobile payment instruments in the customers -business and customers to customers areas.

Preeti Garg \& Manvi Panchal (2017) ${ }^{[6]}$ examined that people have positive opinion about cashless transactions and consider it helpful to fight against corruption, money laundering, and terror funding. The biggest challenge in its adoption is internet security. For smooth implementation of cash less system, it is important to strengthen the security mechanism against cyber fraud.

(Podile \& Rajesh, 2017) ${ }^{[5]}$ examined customer perception on cashless transactions in India. The study concluded that ease of use, incentives, convenience have positive impact on cashless transactions while lack of digital knowledge, poor internet connectivity and defunct POS machines are some negative perception which set back the adoption of cashless system.

(Brahma \& Dutta, 2018) ${ }^{[1]}$ found that while people are getting comfortable with cashless payments but security problems, high transactional costs, poor network coverage, and lack of digital knowledge etc. are some kind of negative perceptions that creates a hurdle in adopting the new payment system.

(Ranjanna, 2018) in her study concluded that majority of the respondents was aware of cashless transactions and agreed that cashless transactions can help to fight against corruption, black money. It helps to reduce the risk of carrying cash and can also faster economic growth. Customers perceived the high level of risk in the application of cash less transactions.

(Rudresha, 2019) ${ }^{[8]}$ Cashless transactions system helps to fight against major illegal or unethical activities in the economy like corruption, black money and terrorism but lack of Internet facilities, cyber security are the main problems which affect the functioning of cashless transactions.

(Kaur P., 2019) ${ }^{[9]}$ concluded that digital payments will save a huge amount of money that is spend annually in printing and maintaining currency. The government needs to take the necessary steps to protect the payment systems from the cyber-attacks.

\section{Materials and Methods}

The research has been undertaken to analyze the benefits and challenges of cashless transactions as perceived by the people. The study is empirical and quantitative in nature where the primary data has been collected through a questionnaire distributed through online methods. The link of the questionnaire was shared on whatsApp and e mailed to various potential respondents in different districts of Haryana. Responses were recorded by 314 respondents. The data was analyzed through SPSS software using frequency table and percentage method.

\subsection{Objectives of the Study}

1. To examine various methods of cashless payments.

2. To analyze the benefits and challenges of cashless payments 
Table 1: Demographic variable of the respondents

\begin{tabular}{|c|c|c|c|}
\hline Variable & Category & Frequency & Percentage \\
\hline \multirow{3}{*}{ Gender } & Male & 163 & 51.8 \\
\hline & Female & 151 & 48.2 \\
\hline & Total & 314 & 100 \\
\hline \multirow{5}{*}{ Age } & $0-18$ Years & 8 & 2.1 \\
\hline & 18-25 Years & 121 & 38.7 \\
\hline & 26-40 Years & 133 & 42.4 \\
\hline & Above 40 Years & 52 & 16.8 \\
\hline & Total & 314 & 100 \\
\hline \multirow{4}{*}{ Marital Status } & Married & 175 & 55.8 \\
\hline & Unmarried & 136 & 43.3 \\
\hline & Others & 3 & 0.9 \\
\hline & Total & 314 & 100 \\
\hline \multirow{7}{*}{ Qualification } & Undergraduate & 37 & 11.8 \\
\hline & Graduate & 87 & 27.8 \\
\hline & Masters & 119 & 37.8 \\
\hline & Doctorate & 47 & 15.1 \\
\hline & Professional & 18 & 5.7 \\
\hline & Others & 5 & 1.8 \\
\hline & Total & 314 & 100.0 \\
\hline \multirow{7}{*}{ Occupation } & Student & 58 & 18.4 \\
\hline & Business & 77 & 24.5 \\
\hline & Private Sector Job & 74 & 23.8 \\
\hline & Government Job & 47 & 15.0 \\
\hline & Farming & 40 & 7.8 \\
\hline & Others & 32 & 10.2 \\
\hline & Total & 314 & 100.0 \\
\hline \multirow{6}{*}{ Income (Monthly) } & $0-25000$ & 117 & 37.2 \\
\hline & $25000-50000$ & 76 & 24.1 \\
\hline & $50000-100000$ & 77 & 24.7 \\
\hline & $100000-200000$ & 37 & 11.7 \\
\hline & Above 200000 & 7 & 2.3 \\
\hline & Total & 314 & 100.0 \\
\hline
\end{tabular}

Table 1 indicates that the proportion of male $(52 \%)$ and female $(48 \%)$ is almost equal in size. A sizeable portion of the respondents aged between 26 years to 40 years $(42.4 \%)$ followed by 18 years to 25 years $(38.7 \%)$ and above 40 years $(16.8 \%)$. Majority of the respondents are having a master's degree $(37.8 \%)$ followed by graduates $(27.8 \%)$, having a doctorate degree (15\%), undergraduates are $(11.8 \%)$ and some of the respondents (5.8\%) are professionals. Occupation wise distribution shows that majority of the respondents are in business $(24.5 \%)$, followed by private sector employees (23.8\%), students
$(18.5 \%)$, respondents in government job are (15\%), farming $(7.8 \%)$ and remaining respondents falls in others category $(10.5 \%)$. Majority of the respondents falls in monthly income group of less than Rs. 25,000 (37.2\%), followed by almost equal number of respondents between Rs. 25,000 to Rs. 50,000, between 50,000 to $1,00,000$ (24\%), between 100,000 to $2,00,000$ is $(11.7 \%$ ) and above Rs. 2,00,000 (2.3\%).

\section{Data Analysis \& Interpretation}

Table 2: Frequency of mostly used payment modes

\begin{tabular}{|c|c|c|}
\hline Options & No. of Respondents & Percentage \\
\hline Cash & 50 & 16 \\
\hline Dr. / Cr. Card & 90 & 28.8 \\
\hline Net Banking & 54 & 17.1 \\
\hline Mobile Wallets & 43 & 13.6 \\
\hline UPI Apps & 77 & 24.5 \\
\hline Total & 314 & 100.0 \\
\hline \multicolumn{3}{|c|}{ Source: Primary Data } \\
\hline
\end{tabular}




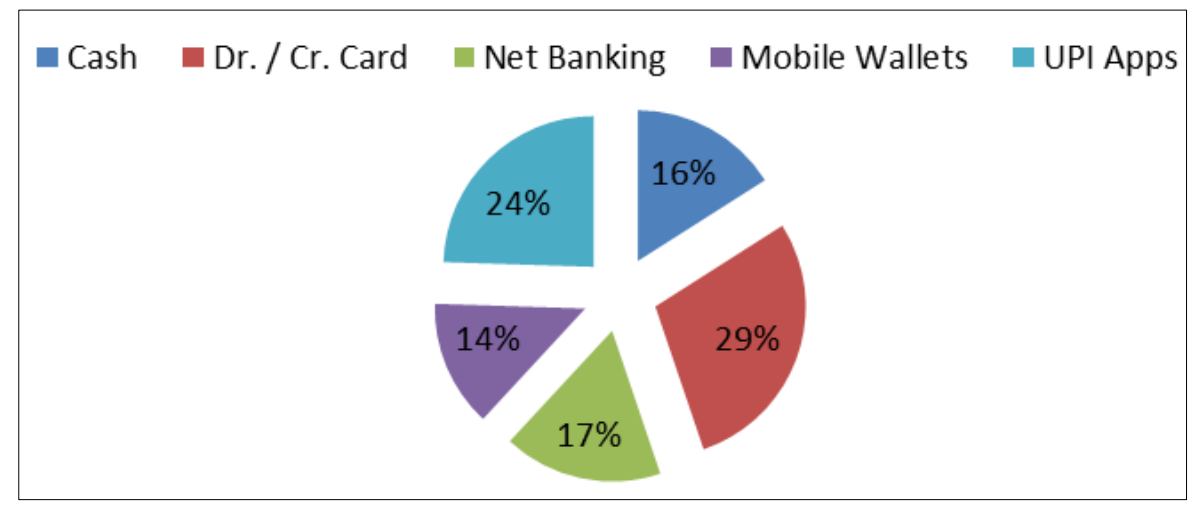

Fig 1: Frequency of mostly used payment modes

Table 2 shows that about $30 \%$ of the respondents consider Dr. Card / Cr. card as the most comfortable mode of payment by respondents followed by UPI apps $(24.5 \%)$.
$17 \%$ of respondents used net banking and $13.6 \%$ used mobile wallets. Cash is preferred by $16 \%$ respondents.

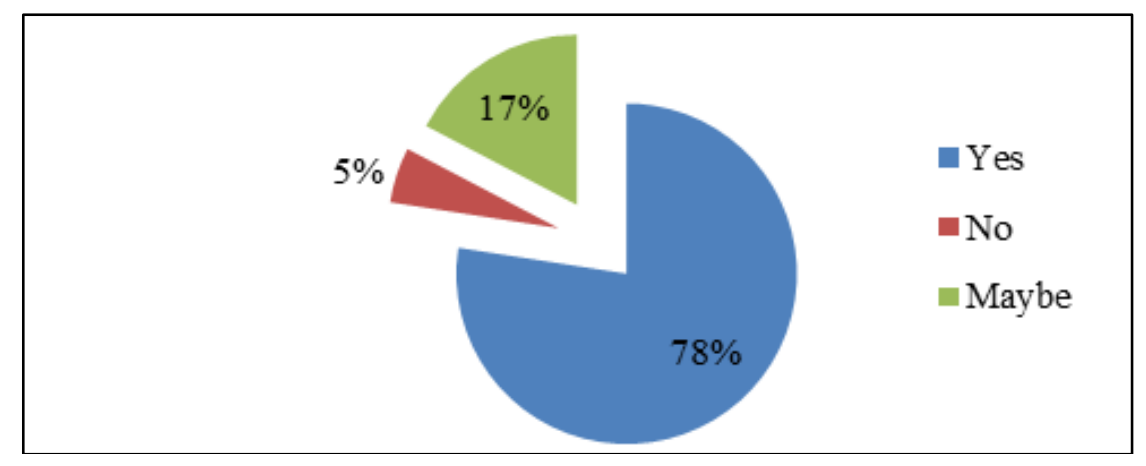

Fig 2: Cashless transactions are better than Cash transactions

Most of the respondents believe that cashless transactions are better than cash transactions. Easy and convenient transactions, high transaction speed, reduce the risk of carrying cash, cash back offers are some benefits perceived by the respondents to consider digital transactions better than cash transactions.

Table 3: Benefits of Cashless transactions

\begin{tabular}{|c|c|c|c|}
\hline & & Frequency & Percentage \\
\hline \multirow{6}{*}{ Easy and convenient means of transactions } & Strongly Agree & 134 & 42.68 \\
\hline & Agree & 109 & 34.71 \\
\hline & Moderately Agree & 47 & 14.97 \\
\hline & Disagree & 8 & 2.55 \\
\hline & Strongly Disagree & 16 & 5.10 \\
\hline & Total & 314 & 100 \\
\hline \multirow{6}{*}{ Reduces risk of carrying cash } & Strongly Agree & 135 & 42.99 \\
\hline & Agree & 110 & 35.03 \\
\hline & Moderately Agree & 42 & 13.38 \\
\hline & Disagree & 15 & 4.78 \\
\hline & Strongly Disagree & 12 & 3.82 \\
\hline & Total & 314 & 100 \\
\hline \multirow{6}{*}{ High Transaction speed } & Strongly Agree & 102 & 32.48 \\
\hline & Agree & 114 & 36.31 \\
\hline & Moderately Agree & 68 & 21.66 \\
\hline & Disagree & 19 & 6.05 \\
\hline & Strongly Disagree & 11 & 3.50 \\
\hline & Total & 314 & 100 \\
\hline \multirow{6}{*}{ Stimulates Economic Growth } & Strongly Agree & 98 & 31.21 \\
\hline & Agree & 109 & 34.71 \\
\hline & Moderately Agree & 56 & 17.84 \\
\hline & Disagree & 37 & 11.78 \\
\hline & Strongly Disagree & 14 & 4.46 \\
\hline & Total & 314 & 100 \\
\hline \multirow{3}{*}{ Controls Black Money } & Strongly Agree & 58 & 18.47 \\
\hline & Agree & 114 & 36.31 \\
\hline & Moderately Agree & 80 & 25.48 \\
\hline
\end{tabular}




\begin{tabular}{|c|c|c|c|}
\hline \multirow{4}{*}{ Reduces Corruption } & Disagree & 49 & 15.61 \\
\cline { 2 - 4 } & Strongly Disagree & 13 & 4.14 \\
\cline { 2 - 4 } & Total & 314 & 100 \\
\hline \multirow{4}{*}{} & Strongly Agree & 67 & 21.34 \\
\cline { 2 - 4 } & Agree & 104 & 33.12 \\
\cline { 2 - 4 } & Moderately Agree & 82 & 26.11 \\
\cline { 2 - 4 } & Disagree & 42 & 13.38 \\
\cline { 2 - 4 } & Strongly Disagree & 19 & 6.05 \\
\cline { 2 - 4 } & Total & 314 & 100 \\
\hline
\end{tabular}

Table 3 shows that the most perceived benefit of the cashless system to India is its ability to reduce the risk of carrying cash and easy and convenient mode of payment, $76 \%$ of the respondents believed that the most important benefit of the cashless economy is convenient and easy method of payment and reduction in risk of carrying cash. In the similar way, $68 \%$, of the respondents said that cashless payment increases the speed of transaction. 54\% believe that the cashless economy will help to reduce corruption and control black money as the money flowing through the system can easily be traced and followed. $65 \%$ of the respondents believe that the cashless transactions stimulate economic growth and believe that digital payment system is positively correlated with the economic development of the country.

4.1 ANOVA Computation: In order to analyze the impact of demographic variables on perceived benefits, ANOVA was carried out. The results are given below. Table 4 gives the result of ANOVA computation on the basis of gender, age, education, occupation and income of the respondents.

Table 4: ANOVA Computation of perceived benefits on the basis of Demographic variables

\begin{tabular}{|c|c|c|c|c|c|c|c|c|c|c|}
\hline \multirow[b]{2}{*}{ Statement/ Attribute } & \multicolumn{2}{|c|}{ Gender } & \multicolumn{2}{|c|}{ Age } & \multicolumn{2}{|c|}{ Education } & \multicolumn{2}{|c|}{ Occupation } & \multicolumn{2}{|c|}{ Income } \\
\hline & $\mathbf{F}$ & Sig. & $\mathbf{F}$ & Sig. & $\mathbf{F}$ & Sig. & $\mathbf{F}$ & Sig. & $\mathbf{F}$ & Sig. \\
\hline Easy and convenient means of transactions & .67 & .412 & 1.37 & .242 & 2.52 & .028 & 2.38 & .038 & .75 & .555 \\
\hline Reduces risk of carrying cash & 1.43 & .232 & .566 & .688 & 5.94 & .000 & 3.75 & .002 & .59 & .666 \\
\hline High Transaction Speed & 1.20 & .274 & .550 & .699 & .437 & .823 & 3.08 & .009 & 2.1 & .069 \\
\hline Cashback offers/ Discounts & 1.89 & .170 & 1.67 & .154 & 2.89 & .014 & 4.98 & .000 & 2.4 & .045 \\
\hline Controls Black Money & 2.34 & .127 & 1.49 & .203 & 1.56 & .168 & 2.48 & .031 & .89 & .467 \\
\hline Controls Illegal Activities & 2.26 & .134 & 1.36 & .246 & 1.55 & .174 & 3.24 & .007 & 1.74 & .144 \\
\hline Reduces Corruption & 4.37 & .037 & 1.59 & .174 & 1.66 & .144 & 3.97 & .002 & 3.15 & .014 \\
\hline
\end{tabular}

The result of ANOVA computation shows that no significant differences in perception of male and female respondents regarding benefits of using cashless modes. This indicates that both male and female customer perceive benefits of cashless modes in similar way. Similarly the ANOVA computation shows that no significant differences are perceived by the respondents on the basis of age and income. However significant differences are shown by respondents in perceived benefits of cashless payments on the basis of their occupation and in some cases on the basis of education.

Table 5: Challenges of Cashless transactions

\begin{tabular}{|c|c|c|c|}
\hline \multirow{4}{*}{ Lack of Security } & & Frequency & Percentage \\
\hline \multirow{5}{*}{ Lack of Digital knowledge } & Strongly Agree & 66 & 21.01 \\
\cline { 2 - 4 } & Agree & 105 & 33.5 \\
\cline { 2 - 4 } & Moderately Agree & 72 & 22.9 \\
\cline { 2 - 4 } & Disagree & 58 & 18.5 \\
\cline { 2 - 4 } & Strongly Disagree & 13 & 4.0 \\
\cline { 2 - 4 } & Total & 314 & 100 \\
\hline \multirow{5}{*}{ Lack of Incentives } & Strongly Agree & 71 & 22.6 \\
\cline { 2 - 4 } & Agree & 89 & 28.4 \\
\cline { 2 - 4 } & Moderately Agree & 72 & 22.92 \\
\cline { 2 - 4 } & Disagree & 62 & 19.65 \\
\cline { 2 - 4 } & Strongly Disagree & 20 & 6.23 \\
\cline { 2 - 4 } & Total & 314 & 100 \\
\hline \multirow{4}{*}{ Inadequate Infrastructure } & Strongly Agree & 13 & 4.09 \\
\cline { 2 - 4 } & Agree & 71 & 22.6 \\
\cline { 2 - 4 } & Moderately Agree & 115 & 36.58 \\
\cline { 2 - 4 } & Disagree & 106 & 33.75 \\
\cline { 2 - 4 } & Strongly Disagree & 10 & 3.31 \\
\cline { 2 - 4 } & Total & 314 & 100 \\
\hline \multirow{4}{*}{} & strongly agree & 33 & 10.5 \\
\cline { 2 - 4 } & Agree & 99 & 31.53 \\
\cline { 2 - 4 } & moderately agree & 85 & 27.04 \\
\cline { 2 - 4 } & Disagree & 85 & 27.04 \\
\cline { 2 - 4 } & strongly disagree & 12 & 3.82 \\
\cline { 2 - 4 } & Total & 314 & 100 \\
\hline
\end{tabular}




\begin{tabular}{|c|c|c|c|}
\hline \multirow{6}{*}{ Poor Internet Connectivity } & Strongly Agree & 66 & 21.01 \\
\hline & Agree & 106 & 33.75 \\
\hline & Moderately Agree & 82 & 31.32 \\
\hline & Disagree & 50 & 17.51 \\
\hline & Strongly Disagree & 10 & 3.31 \\
\hline & Total & 314 & 100 \\
\hline \multirow{6}{*}{ Charges of Online Transactions } & Strongly Agree & 32 & 10.19 \\
\hline & Agree & 66 & 21.02 \\
\hline & Moderately Agree & 98 & 31.21 \\
\hline & Disagree & 97 & 30.89 \\
\hline & Strongly Disagree & 21 & 6.68 \\
\hline & Total & 314 & 100 \\
\hline
\end{tabular}

Above table shows the major challenges which respondents are facing while adopting the cashless system. Majority of the respondents believed that lack of security, digital literacy and poor internet connection are the hurdles in the path of Cashless economy and $41 \%$ people believe inadequate infrastructure is also a problem for cashless system. Some of the respondents believe that charges of online transactions and lack of incentives is hurdle in cashless system.

4.2 ANOVA Computation: In order to test the difference in customer perception of challenges to adoption of cashless modes on the basis of demographic variables, ANOVA was carried out. Table 6 gives the result of ANOVA computation on the basis of gender, age, education, occupation and income of the respondents.

Table 6: ANOVA Computation of perceived Challenges on the basis of Demographic variables

\begin{tabular}{|c|c|c|c|c|c|c|c|c|c|c|}
\hline \multirow{2}{*}{ Statement/ Attribute } & \multicolumn{2}{|c|}{ Gender } & \multicolumn{2}{|c|}{ Age } & \multicolumn{2}{c|}{ Education } & \multicolumn{2}{c|}{ Occupation } & \multicolumn{2}{c|}{ Income } \\
\cline { 2 - 10 } & F & Sig. & F & Sig. & F & Sig. & F & Sig. & F & Sig. \\
\hline Lack of Security & 2.18 & .141 & 6.31 & .000 & 2.62 & .024 & 3.23 & .007 & 3.46 & .009 \\
\hline Lack of Incentives & 2.07 & .151 & 3.93 & .004 & 1.44 & .028 & 2.45 & .034 & 2.99 & .020 \\
\hline Inadequate Infrastructure & .294 & .588 & 2.69 & .052 & .761 & .579 & .773 & .570 & .557 & .694 \\
\hline Lack of Digital Knowledge & 1.15 & .285 & 2.38 & .031 & 3.38 & .005 & .902 & .480 & 1.53 & .194 \\
\hline Poor Internet Connectivity & .041 & .839 & 1.68 & .153 & 3.04 & .011 & .370 & .869 & 1.77 & .135 \\
\hline Charges of Online transactions & .312 & .577 & 2.03 & .090 & 3.86 & .002 & .130 & .986 & 2.60 & .036 \\
\hline
\end{tabular}

The result of ANOVA computation shows that there is no significant difference in perception of male and female respondents regarding challenges of using cashless modes. Similarly the ANOVA computation shows that no significant differences are perceived by the respondents on the basis of occupation and income. However, significant difference was observed in perception of customers on the basis of age and education in most of the cases.

\section{Findings \& Policy implications}

The findings reveal that people are getting comfortable with cashless payments and believe that cashless system is easy and convenient, reduce risk of carrying cash and increases the transaction speed. Cashless transactions can stimulate the economic growth of the country by reducing corruption and illegal activities but there are some negative perceptions that hold back people from adopting the new system. The negative perceptions are like security problems, poor network connectivity, lack of digital knowledge and defunct POS machines. The government should take the some important steps to promote digital literacy and make some policy consideration to ensure cyber security from internet frauds to prepare India for a Cashless economy.

\section{References}

1. Brahma, A., \& Dutta, R. (2018). Cashless Transactions and Its Impact-A Wise Move towards Digital India. International Journal of Scientific Research in Computer Science, Engineering and Information Technology @ 2018.

2. Baghla A. A Study on the future of Digital Payments in India. International Journal of Research and Analytical Reviews 2018;5(4):85-89.
3. Gautam I, Kavidayal PC. Cashless Economy: A Step Towards Green Economy. Mangalmay Journal of Management \& Technology, 2017.

4. Dr. KA Rajanna. Growth of Cash-Less Transactions in India: Challenges and Prospects, IJEDR 2018;6:1. ISSN: 2321-9939.

5. Podile V, Rajesh P. Public Perception on Cashless Transactions in India. Asian Journal of Research in Banking and Finance 2017;7(7):63. https://doi.org/10.5958/2249-7323.2017.00069.4

6. Garg P, Panchal M. Study on Introduction of Cashless Economy in India 2016: Benefits \& Challenges, IOSR Journal of Business and Management (IOSR-JBM). eISSN: $2278-487 \mathrm{X}, \quad$ p-ISSN: 2319-7668. (2018;19(4):116-120.

7. https://www.livemint.com/Leisure/pL9X1CqUhDQHI8 LelxJ5aL/Dont-incentivise-cashless-transactions.html

8. Rudresha. Cashless Transaction in India: A Study", International Journal of Science \& Engineering Development Research (www.ijsdr.org), ISSN:24552631, 2019;4(2):62-67.

9. Kaur P. Cash to Cashless Economy: Challenges \& Opportunities, International Journal of 360 Management Review 2019, 7. April 2019, ISSN: 23207132

10. https://economictimes.indiatimes.com/wealth/spend/5reasons-why-consumers-still-dont-use-digitalpayments/articleshow/64699938.cms?from=mdr.

11. https://www.financialexpress.com/money/why-indianeeds-digital-payments-to-become-an-economicsuperpower/1554658/. 